\title{
$\mathrm{X}$ 線による不均質金属材料の強度に関する研究* \\ (鋳鉄の X 線応力測定について)
}

$$
\text { 平修 二** 林紘三 郎***西 野 征 規 男*** }
$$

\section{X-Ray Investigation on the Strength of Inhomogeneous Metallic Materials}

\author{
(X-Ray Stress Measurement of Cast Iron)
}

by

\author{
Shuji TaIRa, Kozaburo Hayashi and Yukio Nishino \\ (Faculty of Engineering, Kyoto University, Kyoto)
}

The X-ray method of stress measurement is taken as a unique method of non-destructive measurement of local surface stress. In the past few years, the experimental technique and theory of the stress measurement by X-rays have been remarkably improved, and the recent studies in this field have achieved the sufficiently accurate measurement of applied or residual stress for homogeneous metallic materials such as iron, steel, light metal, alloy and so on. However, the method of X-ray stress measurement is not established for inhomogeneous metallic materials such as cast iron, and there remain yet a few problems upon which there is much controversy.

One of the most important problems is to find out the suitable elastic constant for the practical $\mathrm{X}$-ray stress measurement of cast iron.

In the previous papers, the authors discussed the effects of graphite on the deformation behavior of spheroidal and flake graphite cast iron from the lattice strain measured by X-rays. It was also suggested that the X-ray elastic constant obtained at after 3 to 10 stress cycles should be used for $\mathrm{X}$-ray stress measurement of cast iron, and that its constant obtained by X-rays is different from the value obtained by the mechanical method. Besides, there is a wide difference in these values obtained by X-rays in cast iron from those obtained in wrought iron or steel.

In the present investigation, further experiments were made of the application of X-ray stress measurement to cast iron. The elastic constant of spheroidal and flake graphite cast iron was measured by the mechanical method and by X-rays in detail. The X-ray measurement of applied stress and residual stress induced by grinding was carried out using the obtained X-ray elastic constant.

The following conclusions were mainly obtained for these materials ;

(1) The macroscopic elastic modulus $\left(E_{M}\right)$ decreased with the increase of stress. For flake graphite cast iron it decreased having a straight line relation with stress. On the other hand, the elastic modulus pasted through two-stages for spheroidal graphite cast iron. It showed gradual decrease in a linear relation to stress to the stress of $25 \mathrm{~kg} / \mathrm{mm}^{2}$ and, after that, the rate of its decrease became larger until fracture occurred.

(2) The macroscopic elastic modulus $\left(E_{M}\right)$ of flake graphite cast iron was markedly different from that of spheroidal graphite cast iron. It is believed that this wide difference is due to the effect of difference in the shape of the graphite on each deformation behavior.

(3) On the other hand, the X-ray measurement yielded almost the same elastic constant for the two materials. It is considered that the value of the $\mathrm{X}$-ray elastic constant of cast iron is controlled not so much by the shape of graphite as by the volume ratio of graphite to matrix. Therefore, it may be said in conclusion that the elastic constant measured by X-rays should be used in the X-ray stress measurement of cast iron.

(4) If the X-ray elastic constant was used for stress calculation, the applied stress could be measured by the X-rays having a good correlation with mechanically applied stress.

(5) A good correlation between the value measured by the X-ray method and by the mechanical method was found for the residual stress induced by grinding.

(Received Aug. 14, 1968)

* 原稿受理 昭和43年 8 月14日

** 正 会 員 京都大学工学部 京都市左京区吉田本町

*** 学生会員 京都大学大学院 京都市左京区吉田本町 


\section{1 緒 . . 言}

X線による応力測定法は, 金属材料の残留応力を非 破壊的に測定できる唯一の方法として，また局部的な 表面応力の測定方法として，その応用の範囲はきわめ て広い, 最近では測定方法の向上, ならびに測定装置 の著しい改良に伴い，鉄鋼や軽金属などについては， ほとんどいかなる場合についてもきわめて精度の高い 応力測定が可能となっている。しかしながら，鋳鉄の 上ら飞組織的に不均質な金属材料への適用については， そのX線応力測定法の確立が工業上非常に強く要望さ れているにもかかわらず，二，三の研究例を先るにす ぎずな括いくつかの問題が残されている。

鋳鉄についてのX線応力測定上の問題としては, ま ず黒鉛を含をこと，特よび鋳造による異方性をるつこ とから，その弾性定数としていかなる值を用いるべき かという点，和よび結晶粒子が大きい点があげられる。 さらに, 工業上の鋳造物の場合には寸法の過大さ之形 状の複雑さなども難点である。

これらのらら, 測定法上の問題として, 粗大結晶粒 子に関しては, 鉄, アルミニウムなど, 格た一方溶接 部材などについても大きな問題となって拔り，最近い くつかの研究がすすめられているようであるので，こ こでは取り扱わない。また寸法, 形状から生ずる問題 に関しては; X線測定装置の改良拉よび取扱 方法の向上などによってかなり解決されらり 放るようで放る。したがって本報告では，鋳 鉄の場合にX線応力測定の基礎式に用いる弾 性定数としていかなる值をとるべきかという

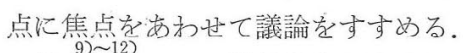

前報に抢いて，機珹的負荷応力とX線によ って求めた格子ひず死をもとにして鋳鉄の変 形機情を明らかにするとともに, 鋳鉄のX線 的弾性係数 $E_{x}$ が，初期の応力の繰返しで やや減少し, 数回の繰还しの捘に曹る一定值に飽和寸 ること定報告した。また，このようにして求められる 值は，機械的に測定した值とは大きく異なっているら 壳に，鋳鉄のマトリックスにかなり近いと考光られる $0.86 \% \mathrm{C}$ 炭素鋼についての值，西るい性線回折淔 接関保するフェライト相に最も近いと考克られる鉄に ついて, 得られた值からも非常に離れているために, 鋳鉄のX線応力測定に用いる弾性定数の選択飞は注意 しなければならないことを示唆した。气の場合に曲げ
試験片を用いて実験を行なったが，鋳鉄では引張り之 压縮とで变形挙動か異なるたると、曲げでは純引張り や純庄縮とは異なった様相を呈している可能性がある。 そこで, 本報では単純引張りを与党た場合について前 報と同様な実験を行ない，これよりX線的弾性定数を 求め, これ劣用いて外部負荷応力および, 研削残留応 力の測定の可能性について実験的検討を加える.

\section{2 実 験 方 法}

本研究に使用した村料は, Table I に示す化学成分

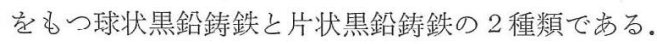
外部負荷応力を与觉る試験片のうち, 機械加工材と乙 ては, 直径 $30 \mathrm{~mm}$ 長さ $600 \mathrm{~mm}$ の鋳込材から, Fig. 1 に示す形状寸法に旋削加工を施したものを用いた。 さらにとの後 $550^{\circ} \mathrm{C} て ゙ 2$ 時間真空中に焼なすしを施し たものを焼なるし材とした、焼なまし材の組織をFig. 2 亿, また単純引張試験結果をFig. 3 亿示す。組織は

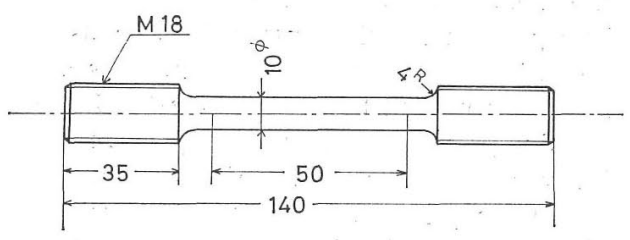

Fig. 1. Shape and dimension of specimen.

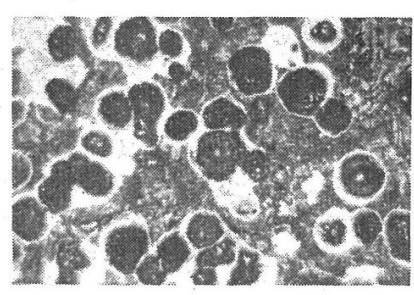

(a) Spheroidal graphite cast iron.

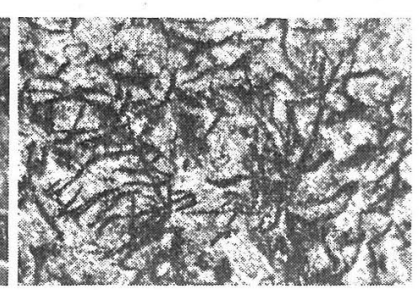

(b) Flake graphite cast iron.

Fig. 2. Microstructure of test materials $(\times 50)$.

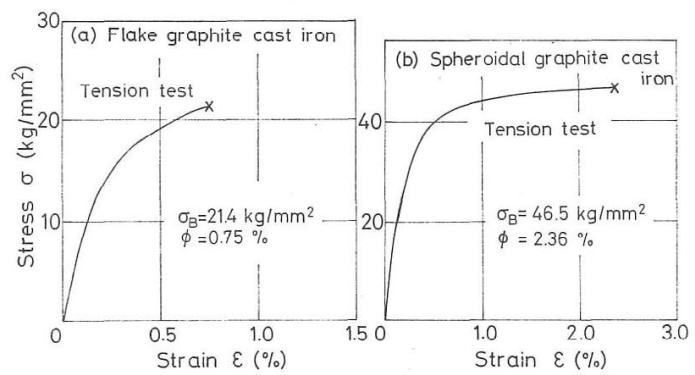

Fig. 3. Stress-strain relation.

Table I. Chemical composition of test materials.

\begin{tabular}{l|c|c|c|c|c|c|r|r|r|r}
\hline & C. & Si & Mn & P & S & Ni & Cr & Mo & Cu & $\mathrm{Mg}$ \\
\hline Spheroidal graphite cast iron & 3.57 & 2.83 & 0.59 & 0.022 & 0.015 & - & - & - & 0.05 & 0.058 \\
Flake graphite cast iron & 3.29 & 2.40 & 0.66 & 0.068 & 0.010 & 0.01 & 0.17 & 0.02 & 0.20 & - \\
\hline
\end{tabular}


球状黒鉛鋳鉄はブルスアイ組織であり, ‘片状黒鉛鋳鉄 では, マドリッグスはすベで゚ーライトで占めあれで いる。さまた全断面積に対する黒鉛の面積割合は，それ ぞれ約20\%和よび23\%であった。

引張応力の負荷には島津製リーレー武万能試験機を 用い，ひずみの測定には，機械的方法としてはマルテ ンス鏡を，またX線的方法としては試験機に特に設置 した た X線応力測定装置(東芝製構造“物用応力測定装置) を用いた。採用したX線実験条件をまとめてTable II に示す。なお格子ひずみの計算方法は前報の場合とま ったく同様であるのでここでは省略する，また，応力 の計算には次の式を用いた。

Table II. Measuring apparàtus, method and condition. of X-ray diffraction technique.

\begin{tabular}{l|l}
\hline & $\begin{array}{l}\text { Parallel beam type X-ray } \\
\text { stress analyzer with } \\
\text { Measuring apparatus }\end{array}$ \\
& $\mathrm{Co}-\mathrm{K} \alpha, \mathrm{Cr}-\mathrm{K} \alpha$ \\
Characteristic X-ray & $\mathrm{Fe}, \mathrm{V}$ \\
Filter & $2 \times 2 \mathrm{~mm}^{2}$ \\
Slit & $30 \mathrm{kV}$ \\
Tube voltage & $10 \mathrm{~mA}$ \\
Tube current & $1 / 8$ height method \\
Measuring method &
\end{tabular}

$$
\sigma_{X}=-\frac{1}{2} \cdot \frac{E}{1+\nu} \cdot \cot \theta_{0} \cdot \frac{\partial\left(2 \theta_{\psi}\right)}{\partial\left(\sin ^{2} \psi\right)}
$$

ここで $\theta_{0}$ は無ひずみ状態のブラッグ角であり， $\theta_{\psi}$ は 試料表面法線方向に対して

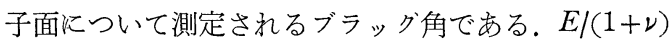
は弾性定数であり，緒言で述べたように本論文はこの 定数にいかなる値を用いるべきかについて議論する。 残留応力の測定用の試料としては $11 \times 30 \times 200 \mathrm{~mm}^{3}$ の鋳込材に，切込深さを $0.2 \mathrm{~mm}$ とし，研削剤を多 量に用いて板厚 $8 \mathrm{~mm}$ まで研削加工を施したものを 使用した。この場合に残留応力の機械的な測定は, 平, 吉岡が用いた方法によった。

\section{3 実験結果と検討}

\section{$3 \cdot 1$ 機械的弾性定数について}

まず, 片状黒鉛鋳鉄について, 応力の負荷, 除荷を 繰り返しながら，各回の最大応力を段階的に増加させ， 各回についてその最大ひずみと除荷後の永久ひずみ, およびそれらの差の回復可能なひずみを測定した結果 をFig. 4 に示す. 図からわかるように, 片状黒鉛鋳鉄 の応力ーひずみ曲線には, 応力の低い部分においても 直線部分はほとんど存在せず, $7.5 \mathrm{~kg} / \mathrm{mm}^{2}$ というき わめて低い応力を与えた場合でもすでに永久ひずみが 観察されている，また，回復可能なひずみを表わす曲 線も, この応力值付近からはやくも湾曲しており, こ

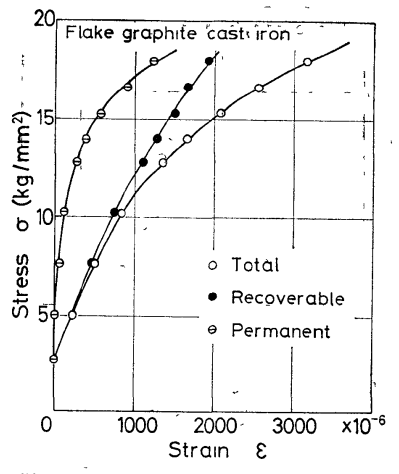

Fig. 4. Change in total strain, permanent strain and recoverable strain of flake graphite cast iron.

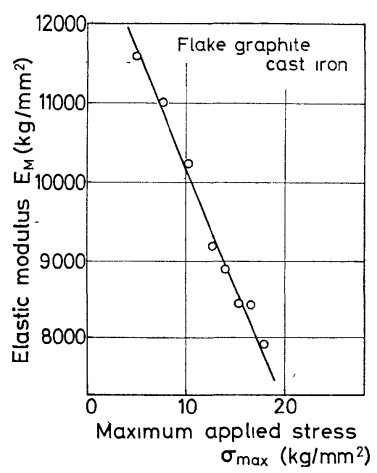

Fig. 5. Change in mechanical elastic modulus of flake graphite cast iron.

のことは, その弾性係数 $E_{M}$ が応力とともに変化す ることを示している.この点をより明雄に示すために， 各回について求められる弾性係数 $E_{M}$ を, 各回の 大応力で整理した結果を Fig. 5 に示す.これより, 片状黒鉛鋳鉄の弾性係数 $E_{M}$ は, 最大負荷応力 $\sigma_{\max }$ と次のよらな関係を有するものと考学られる。

$$
E_{M}=E_{M 0}-m \cdot \sigma_{\max }
$$

ここで， $E_{M 0}$ は Fig. 5 に表される直線を延長して求 められる $\sigma_{\max }=0$ のときの弾性係数を，また， $m$ はこ の直線の傾きを表わしており， $E_{M 0} \cong 13000 \mathrm{~kg} / \mathrm{mm}^{2}$, および $m \cong 300$ が得られた。

応力の繰返しによる影響を調べるために，10 kg/ $\mathrm{mm}^{2}$ の応力值まで負荷, 除荷を繰り返したときの応 力ひずみ曲線の変化をFig. 6 に示す. 1 回めの負荷, 除荷の過程では大きなループを描いているが，繰返し 数が増すにつれて全ひずみ，扎よび永久ひずみはわず かずつ増加するよらであるが，3〜10回の繰返しで飽 和している.この場合, 弾性係数 $E_{M}$ は繰返し数によ ってほとんど変化せず，約 $10000 \mathrm{~kg} / \mathrm{mm}^{2}$ であった。 この值はFig. 5 に和ける $\sigma_{\max }=10 \mathrm{~kg} / \mathrm{mm}^{2}$ に拉ける 弾性係数に等しいことがわかる.

球状黒鉊鋳鉄に関する同様の実験結果を Fig. 7〜9 


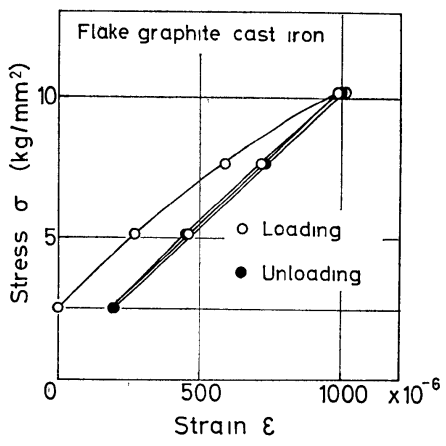

Fig. 6. Stress-total strain relation of flake graphite cast iron in the case of the same stress cycles.

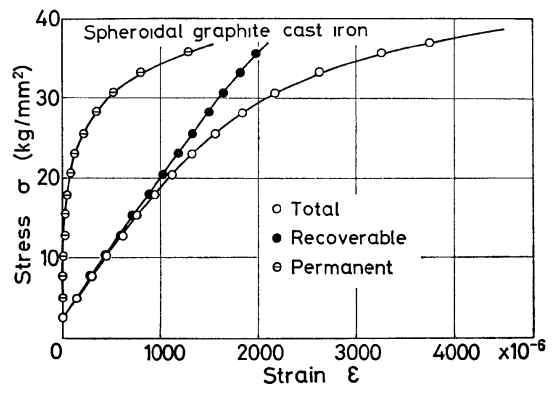

Fig. 7. Change in total strain, permanent strain and recoverable strain of spheroidal graphite cast iron.

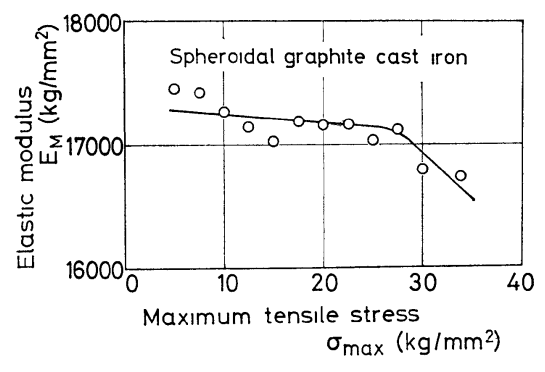

Fig. 8. Change in mechanical elastic modulus of spheroidal graphite cast iron.

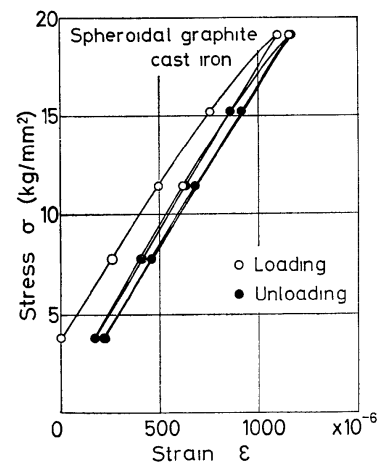

Fig. 9. Stress-total strain relation of spheroidal graphite cast iron in the case of the same stress cycles.
に示す. Fig. 7 に扔いて, 応力と全ひずみの関係がほ ぼ直線的とみなしらる低い応力段階においても，永久 ひずみは徐々に增加して拉り, 約 $20 \mathrm{~kg} / \mathrm{mm}^{2}$ あたり から增加の程度が激しくなり, 約 $28 \mathrm{~kg} / \mathrm{mm}^{2}$ からは 急激に増加していることがわかる，回復可能なひずみ を表わす曲線は低い応力付近ではやや湾曲しながらも 注ぼ直線的であるが，永久ひずみが急激増加する 28 $\mathrm{kg} / \mathrm{mm}^{2}$ あたりから湾曲の度合いが増加している。 これより，その弾性係数 $E_{M}$ は，Fig. 8 にみられる ように, 約 $28 \mathrm{~kg} / \mathrm{mm}^{2}$ までは応力の増加にしたがっ て直線的にやや減少していき，その後は急減する傾向 を示すことがわかる，乙たがって球状黒鉛鋳鉄に打い ても, 変形期間 (あるいは応力段階) を二つの領域に わければ。それぞれについて(2)式があてはまると考兄 られる. 同一応力を繰返し負荷, 除荷を施した場合に 得られたFig. 9 は, 片状黒鉛鋳鉄についての場合々傾 向的にはまったく同様である.

鋳鉄はその組織中に黒鉛を含むために, きわめて複

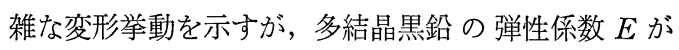
$300 \sim 700 \mathrm{~kg} / \mathrm{mm}_{14}^{2}$ であり, かつその破壊強度 $\sigma_{B}$ が $2 \mathrm{~kg} / \mathrm{mm}^{2}$ 程度以下と, いずれも炭素鋼にほぼ近いと 考光られるマトリックスについてのこれらの值と比較 して無視しらるほど小さい。また，前報の結果などを あわせ考劣ると，黒鉛は引張応力をほとんど分担せず， 空孔と同様な役割を有するものと考劣ることができる。 したがって，鋳鉄の変形に及淁す黒鉛の効果として考 えられることは, まず, 黒鉛の介在により, 強度を決 定するマトリックスの断面積が減少することがあげら れる.さらに，このマトリックスが変形に対して有効 飞働きうるか否かが，黒鉛の形状，およびその分布状 態なぞによって大きな影響を受け，これが，球状黒鉛 鋳鉄と片状黒鉛鋳鉄飞打いて機械的弾性定数の值が大 幅に異なる原因の一つであると考兄られる。本実験に 打いても, 片状黒鉛鋳鉄と球状黒鉛鋳鉄とで, 含有炭 素量ならびにマトリックスが全断面積に対して占める 割合が注淁等しいにもかかわらず，(2)式で示される $E_{M 0}$ としてそれぞれ. $13000 \mathrm{~kg} / \mathrm{mm}^{2}, 17500 \mathrm{~kg} /$ $\mathrm{mm}^{2}$ の值が得られている.

さらに，応力が增大するにつれて弾性係数 $E_{M}$ が 次第に減少するのは, G. N. J. Gilbert が考兄ている ように, 黒鉛の応力集中効果により, 黒鉛周囲のマト リックスに局部的な収縮が生じたり，き裂や空孔が発 生することにより，マトリックスの有効断面積がしだ い減少し, したがってその弾性係数は減少するもの と考えられる。

片状黒鉛鋳鉄と球状黒鉛鋳鉄とで, その变化の様相 が異なるのは，含まれる黒鉛の応力集中効果が異なる ためであると考光られ，非常に応力集中効果が高いと 
考えられる片状黒鉛を多数含む片状黒鉛鋳鉄において は, きわめて低い応力值から黒鉛先端のマトリックス 中に微小なき裂が発生するために, 弾性定数は応力の 増加につれて急激に減少する. 一方, 球状黒鉛鋳鉄で は, 含有黒鉛の応力集中効果は比較的少なく, 局部的 な塑性変形の進行，あるいはき裂の発生は，約 $25 \mathrm{~kg} /$ $\mathrm{mm}^{2}$ 以下の応力においては黒鉛突起のようなごく限 られた領域に掞いてのみ抗こるために弾性係数 $E_{M}$ の 減少の程度は小さいものと考える.さらにこの応力以 上になると，いずれの黒鉛においても塑性領域に入る とともにき裂などが顕著に発生するために, 弾性係数 $E_{M}$ が急減するものと考えられる.

\section{$3 \cdot 2 \mathrm{X}$ 線的弾性定数について}

Fig. 10 は，片状黒鉛鋳鉄について，抗張力の $1 / 2$ よ りやや低い $10 \mathrm{~kg} / \mathrm{mm}^{2}$ の応力を単純引張りによって 繰り返して加え, その 1 回め执よび10回めの引張変形 中の機械的負荷応力と $\mathrm{Co}-\mathrm{K} \alpha$ 線が測定した格子ひず みとの関係を示したものである. 第 1 回めの負荷, 除 荷過程では，やや開いたループを描くが，10回めでは 閉じて両者の関係はほぼ直線的になることがわかる。 また,ループの傾きは10回めまでは 1 回めに比べてや や減少している.これらの傾向は前報で述べた曲げ試 験片を用いた場合とほぼ同様である，なお，各回につ いてその除荷過程より求めたX線的弾性係数 $E_{X}$ は, それぞれ $17800 \mathrm{~kg} / \mathrm{mm}^{2}$ および, $17000 \mathrm{~kg} / \mathrm{mm}^{2}$ で

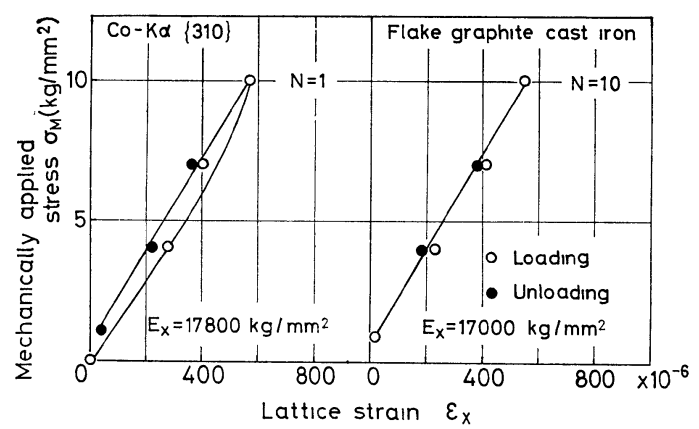

Fig. 10. Change in lattice strain of flake graphite cast iron.

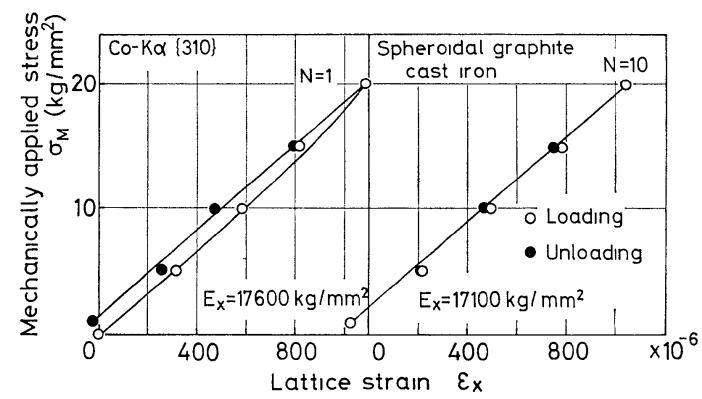

Fig. 11. Change in lattice strain of spheroidal graphite cast iron.
あった。

一方, Fig. 11 に示される球状黒鉛鋳鉄の場合も片 状黒鉛鋳鉄の場合とほぼ同様な傾向を示している，同 様にして求められた X線的弾性係数 $E_{X}$ は, 17600 および $17100 \mathrm{~kg} / \mathrm{mm}^{2}$ であった。

ここで注目されるのは，前節で述べたよらに機械的 弾性係数 $E_{M}$ は, 片状黒鉛鋳鉄 と球状黒鉛鋳鉄とで 大きく異なるにもかかわらず，X線的に測定すると， 両者で湟ぼ等しい值をとることである．X線的に測定 される弾性係数は試験片全体にかかっている公称応力 （すなわち荷重を試験片断面積で除したもの）を，マ トリックス中のフェライト相のひずみで除したものに 対応する. 応力集中効果などのためにフェライト相に おけるひずみは不均一であるが，実際にX線的に測定 されるのはその体積的な平均值であるものと考えられ る.したがって, 適当なモデルに従って鋳鉄のX線的 弾性係数 $E_{X}$ を解析すると, 含むれる黒鉛（あるい は空孔とみなしてよい）の形状のいかんにかかわらず， マトリックスに対して占める黒鉛の体積割合に関係し てくる.しかるに，本実験で使用した片状黒鉛鋳鉄と 球状黒鉛鋳鉄とは，第 2 章で述べたように，黒鉛の面 積割合, したがって体積割合はほぼ等しいことから， X線的に測定する場合には両者でほぼ同じ值の弾性係 数が測定されるのであろらと考劣られる。

\section{$3 \cdot 3$ 鋳鉄の X 線応力測定について}

前報に括いて報告したように, 鋳鉄のX線的弾性係 数 $E_{X}$ は, ある応力值まで繰返し負荷, 除荷を施す と, 初期の繰返しで減少し，3〜10回の繰返しの後に ある一定值に飽和するといら結果が得られている。そ こでは, 曲げ試験片の引張側表面について測定を行な ったが，前節で示したように，単純引張りを与えた場 合においても同様な結果が得られるようである。

一般に，工業的に応力測定を行なら場合には，材料 はなんらかの加工を受けたままの状態にあることが汪 とえどであり， $\mathrm{X}$ 線的弾性係数 $E_{X}$ としては，応力 の繰返しによって飽和した值を用いるのが妥当である と考えられる。したがって本節の以下の議論に秝いて はいずれも第10回めの除荷過程について求められた值 を用いて検討をすすめる，そこでまず，10回めの除荷

Table III. X-ray elastic constant.

\begin{tabular}{l|c|c|c}
\multicolumn{3}{c|}{$\frac{1+\nu}{E}$} \\
\hline & \multicolumn{2}{|c|}{ X-ray method } & Mechanical \\
method \\
\cline { 2 - 4 } & $\mathrm{Co}-\mathrm{K} \alpha$ & $\mathrm{Cr}-\mathrm{K} \alpha$ & \\
\hline Spheroidal graphite cast iron & 0.781 & 0.595 & 0.744 \\
Flake graphite cast iron & 0821 & 0.747 & 1.280 \\
\hline & \multicolumn{3}{c}{$\left(\times 10^{-4} \mathrm{~mm}^{2} / \mathrm{kg}\right)$}
\end{tabular}


過程より求めた $\mathrm{X}$ 線的弾性定数を, $\mathrm{X}$ 線応力測定の基 礎式，(1)式に用いられる $(1+\nu) / E$ の形で整理すると， Table III が得られる。これには, $\mathrm{Co}-\mathrm{K} \alpha$ 線および $\mathrm{Cr}-\mathrm{K} \alpha$ 線を用いてX線的に測定した值と，機械的方 法により求めた值とをまとめて示してある.

Table III に示されるX線的弾性定数を用いて，応 力負荷履歷の不明な片状黒鉛鋳鉄および球状黒鉛鋳鉄 の加工材について, 機械的負荷応力と, X線によって 測定した応力との関係を, それぞれ Fig. 12 および13 に示す.この場合, 最大負荷応力をこれまでの実験結 果同様それぞれ10执よび $20 \mathrm{~kg} / \mathrm{mm}^{2}$ とした．無負荷 時の残留応力はそれぞれ， -40 および $-7 \mathrm{~kg} / \mathrm{mm}^{2}$ である. 図に示されている実線は，横軸と $45^{\circ}$ をす 直線であり，この直線からのばらつきがかなり小さい ことより用いた弾性定数が適当であることが知られる。

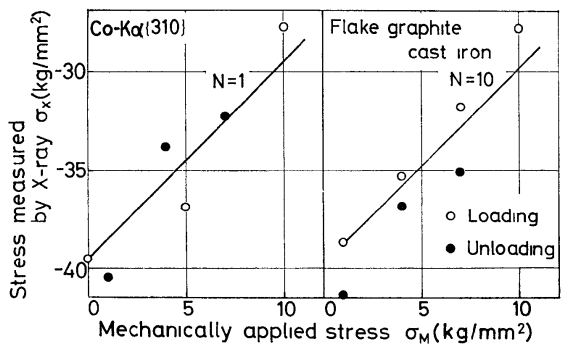

Fig. 12. Correlation of stress measured by X-ray and mechanical method of flake graphite cast iron.

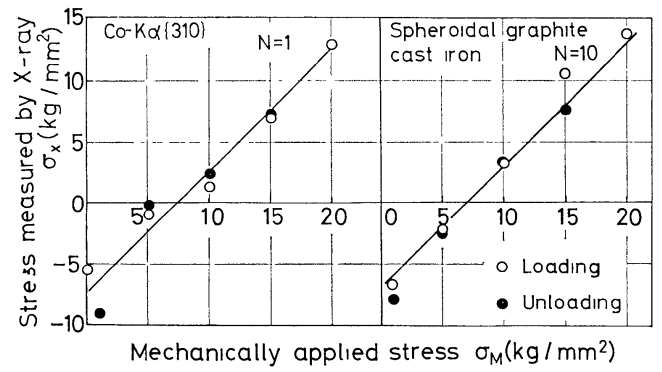

Fig. 13. Correlation of stress measured by X-ray and mechanical method of spheroldal graphite cast iron.

次に，研削加工によって生じた残留応力の深さ方向 分布を測定した結果について述べる。

Fig. 14 は, 片状黒鉛鋳鉄について研削残留応力を $\mathrm{Co}-\mathrm{K} \alpha$ 線および $\mathrm{Cr}-\mathrm{K} \alpha$ 線で測定した場合，ならび に機械的な方法により測定した場合の, 板厚方向への 残留応力分布を示している. 表面残留応力は一 $20 \mathrm{~kg} /$ $\mathrm{mm}^{2}$ 程度であり, $50 \mu$ 程度内部に执いては約 $2 \mathrm{~kg} /$ $\mathrm{mm}^{2}$ の引張応力に転じ, それより内部ではほぼ 0 に 漸近している.これら三つの方法で測定した值はいず れもほぼよい一致を示している。

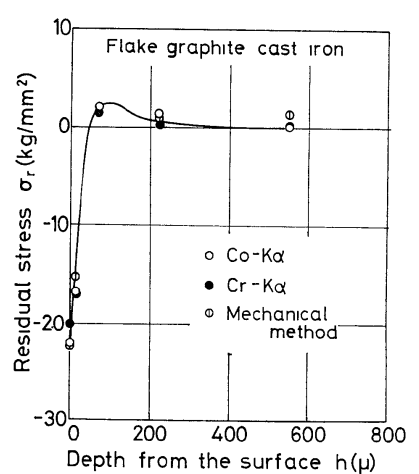

Fig. 14. Distribution of residual stress induced in grinding specimen of flake graphite cast iron.

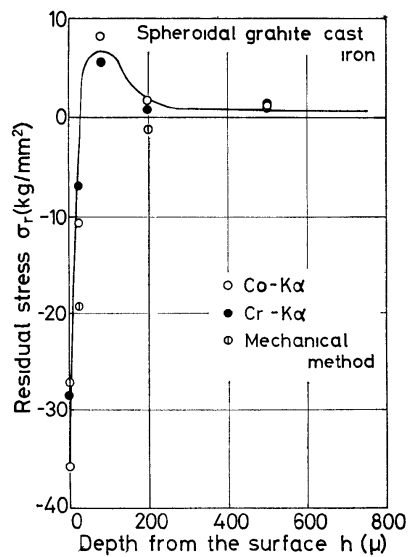

Fig. 15. Distribution of residual stress induced in grinding specimen of spheroidal graphite cast iron.

一方，Fig. 15 は球状黒鉛鋳鉄に関する同様の実験 結果である.この場合も残留応力分布の状態は片状黒 鉊鋳鉄の場合とほぼ同様であり, やはりいずれの方法 で測定してもかなりよい一致を示していることがわか る.

これらの実験結果より, Table III に示される弾性 定数を用いることが残留応力測定についても適当であ ることがわかる、すなわち，鋳鉄のX線応力測定に用 いる弾性定数としては, マトリックスにほぼ近いと考 えられる炭素鋼のX線的弾性係数に，マトリックスの 全体に対して占める体積割合を考え合わせた值を用い ればよいことになる。

なお，このような不均質金属材料の機械的，および X線的弾性係数についての詳しいモデル解析は別に述 ベる予定である。

\section{4 結論}

以上の実験結果, および考察をもとにして本報告の 要点を述べると次のと扤りである。

（1）鋳鉄の機珹的弾性係数 $E_{M}$ は, その最大負荷応 力に依存し，片状黒鉛鋳鉄では最大負荷応力が増加す 
るとともに直線的に減少する。一方, 球状黒鉛鋳鉄に ついてもやはり直線的減少するが，漸減の領域と急 減の領域の二つから構成される。この急激に減少する 領域が, 片状黒鉛鋳鉄についての弾性俰数 $E_{M}$ の減少 の過程に対応する。

（2）片状黒鉛鋳鉄と球状黒鉛鋳鉄とで機械的弾性係 数 $E_{M}$ は大きく異なる. これはマトリックスの変形に 対して果たす役割が含まれる黒鉛の形状によって大き く異なるためであると考兄られる。

（3）鋳鉄のX線的弾性係数 $E_{X}$ は，含まれる黒鉛の 形状分布状態のいかんにかかわらず，マトリックスに 対して占める黒鉛の体積割合に関係する.

なお，この点に関しては詳しいモデル的解析の研究 を進めている.

（4）なんらかの加工を受けた鋳鉄材料についてX線 応力測定法を適用する場合には, 焼なむしを施した処 女材について応力を数回繰り返した後か, あるいは加 工状態のままでX線的比求められる弾性定数を用いる のが適当である。あるいは，(3)で述べた点を考慮して マトリックスに添涪近いと考光られる鋼についてのX 線的弾性定数より換算した值を用いるのがよいようで ある。このようにして求められる值を用いてX線応力 測定を行なった結果, 外部負荷応力についても, また 研削残留応力についても，機械的に測定した值とよい 一致が得られた。

最後に, 本研究実施にあたり, 鋳鉄材料をご提供い ただいた三菱重工（株）京都製作所の兽我美豊氏なら
びに服部満雄氏に深く感謝する。

(昭和 43 年 5 月 22 日 日本材料学会第17期総会講寅会化て講演)

\section{参 考 文 献}

1）西原利夫，小島公平， 日本機械学会論文集， 4, 110 (1938).

2）青山咸恒，並川宏彦，材料，15，858 (1966).

3) Hauk, V., Arch. Eisenhüttenwes, 23, 353 (1952).

4) Hauk, V., Arch. Eisenhüttenwes., 26, 449 (1955).

5）小島公平ほ加，“ $X$ 線応力測定法”（1966）養賢堂

6）細川智生ほか，第 4 回X線材料強度に関する討論会前刷， p. 70 (1967).

7）英 崇夫, 福良二郎, 藤原情夫, 材料, 16, 948 (1967).

8）平修二，松木健次，17，1053 (1968).

9）平 修二，林紘三郎，材料， 15, 851 (1966).

10）平 修二，林紘三郎，西野征規男，材料， 16, 1020 (1967).

11) Taira, S., and K. Hayashi, Proc. 10th Jap. Cong. Test. Mat., p. 6 (1967).

12) Taira, S., K. Hayashi, and Y. Nishino, Proc. 11th Jap. Cong. Mat. Res., p. 1 (1968).

13）平 修二, 吉岡靖夫, 材料, 12, 123 (1963).

14）日本金属学会釷造分科会編, “球状黒銓鏻鉄の理論之実 際” (1966) 丸善

15) Gilbert, G. N. J., B.C.I. R. A. J., 7, 745 (1959); 9, 347 (1961); 11, 512 (1963); 12, 170 (1964).

16）平 修二, 林紘三郎, 西野征規男, 第12回材料研究連合 講演会前刷 , p. 33 (1968). 